\title{
PEMBELAJARAN EKONOMI DALAM ISLAM PADA MATERI MUDHARABAH DI PONDOK PESANTREN
}

\author{
Learning Economy In Islam In Mudharabah Materials In Pondok Pesantren
}

\section{Muhammad Tri Ramdhani ${ }^{1,2,3 *}$}

Lastaria $^{2}$

Ariyadi $^{3}$

\author{
1,2,3 Universitas Muhammadiyah \\ Palangkaraya, Palangka Raya, Central \\ Kalimantan, Indonesia \\ *email: \\ muhammadtriramdhani@gmail.com
}

\begin{abstract}
Abstrak
Pembelajaran merupakan kegiatan yang dilakukan untuk memfasilitasi dan meningkatkan intensitas dan kualitas belajar pada diri peserta didik. Pembelajaran harus menghasilkan belajar, tapi tidak semua proses belajar terjadi karena pembelajaran, proses belajar juga bisa terjadi dilingkungan sosial-kultural dalam lingkungan masyarakat. Hakikat dalam Pembelajaran sebagai suatu sistem atau proses membelajarkan subjek didik/pembelajar yang direncanakan atau didesain, dilaksanakan, dan dievaluasi secara sistematis agar subjek didik/pembelajar dapat mencapai tujuan pembelajaran secara efektif dan efisien. Adapun target yang akan didapatkan ialah untuk mengetahui pembelajaran ekonomi dalam Islam
\end{abstract}

Pada proses ini diwali dengan kegiatan pendahuluan yaitu memberikan stimulus terlebih dahulu kepada peserta didik untuk proaktif dalam pembelajaran yang nantinya akan dilaksanakan serta menampilkan beberapa permasalahan dalam kehiduan yang terkait pada materi pembelajaran. Kemudian dilanjutkan dengan kegiatan inti diawali dengan mengamati seperti meminta peserta didik untuk membaca buku referensi tentang mudharabah dan juga diberikan kesempatan untuk mengamati beberapa permasalan apa yang terjadi terkait dengan materi yang dibahas serta mengamati slide yang ditampilkan. Selanjutnya dilakukan proses menanya degan proses peserta didik untuk menjawab pre test yang diberikan berupa pertanyaan, kemudian memberikan kesempatan peserta didik untuk mengajukan pertanyaan terkait hasil pengamatan yang dilakukan sebelumnya tentang mudharabah serta menampung pertanyaan dari mereka dnn member kesempatan kepada tiap peserta didik atau menunjuk secara acak menjawab pertanyaan dari temannya.

\footnotetext{
Abstract

Learning is an activity carried out to facilitate and increase the intensity and quality of learning in students. Learning must produce learning, but not all learning processes occur because learning, learning processes can also occur in the socio-cultural environment in the community environment. The Nature of Learning as a system or process of learning students / learners who are planned or designed, implemented, and evaluated systematically so that students I learners can achieve their learning goals effectively and efficiently. The target will be obtained is to find out economic learning in Islam

In this process begins with preliminary activities that provide stimulus in advance to students to be proactive in learning that will be implemented and present some problems in life related to learning material. Then proceed with the core activities beginning with observing such as asking students to read a reference book about mudaraba and also given the opportunity to observe some questions about what happened related to the material discussed and observe the slides that are displayed. Then the questioning process is carried out with the process of students to answer the pre test given in the form of questions, then provide the opportunity for students to ask questions related to observations made previously about mudaraba and accommodate questions from them and give opportunity to each student or point randomly to answer a question from his friend.
} 


\section{Pendahuluan}

Pendidikan adalah suatu kebutuhan bagi setiap orang, oleh karenanya pendidikan perlu mendapatkan perhatian semua pihak, baik pemerintah, orang tua, maupun masyarakat bekerja sama dengan baik.

Pendidikan merupakan usaha sadar untuk membentuk anak yang mulia, berbudi pekerti luhur. bertanggung jawab serta usaha pendewasaan diri. Hal ini sesuai dengan UU RI Nomor 20 tahun 2003 sebagai berikut: Pendidikan adalah usaha sadar dan terencana untuk mewujudkan suasana belajar dan proses pembelajaran agar peserta didik secara aktif mengembangkan potensi dirinya untuk memiliki kekuatan spiritual Keagamaan, pengendalian diri, kepribadian, kecerdasan, akhlak mulia, serta keterampilan yang diperlukan dirinya, masyarakat, bangsa dan negara.

Peningkatan kualitas sumber daya manusia yang dalam masa sepuluh tahun ini makin ramai dibicarakan di tengah masyarakat dan berbagai upaya terus dilakukan, terutama peningkatan kualitas pendidikan pada sekolah-sekolah. Namun muncul pemasalahan lain, mampukah pendidikan sekarang memenuhi standar keilmuan yang berkembang pesat, baik dalam kualitas dan kuantitasnya sehingga dapat meningkatkan sumber daya manusia, yang mana pemerintah berusaha melakukan berbagai usaha dalam mengatasi masalah ini.

Pendidikan di Indonesia diarahkkan dalam rangka membentuk manusia yang memiliki keseimbangan untuk mengabdi kepada pribadi, sosial dan akhirat. Oleh sebab itu, pendidikan dalam hal ini pendidikan agama Islam mendapat tempat yang layak. Di semua jenjang sekolah pendidikan agama Islam mempunyai peran yang sangat penting karena hasil proses pendidikan agama Islam diharapkan dapat mempertinggi akhlak manusia. Disamping itu pendidikan agama Islam juga diharapkan dapat menciptakan manusia yang dapat mengamalkan ajaran-ajaran Islam dengan baik, dalam kehidupan sehari-hari sehat jasmani dan rohani sehingga terdapat keseimbangan dunia dan akhirat, sebagai wahana untuk meningkatkan dan mengembangkan kualitas sumber daya manusia beriman dan bertaqwa kepada Tuhan yang Maha Esa, beretika, beradab dan berwawasan tinggi yang memiliki pengetahuan dan keterampilan, kepribadian yang mantap dan mandiri terhadap masa depan dengan penuh tanggung jawab yang seutuhnya terhadap bangsa dan negara. Pada konteksnya sebuah pendidikan akan berjalan dengan koridornya terlihat dari bagaiman sebuah proses pembelajaran yang terjadi pada komponen-komponen yang terlibat didalamnya. Belajar adalah proses dimana tingkah laku ditimbulkan atau diubah melalui latihan atau pengalaman (James O.Whittaker Wasty Sumanto, 1987). Sedangkan pembelajaran adalah usaha sadar guru untuk membantu siswa atau anak didik, agar mereka dapat belajar sesuai dengan kebututuhan dan minatnya

Pembelajaran merupakan kegiatan yang dilakukan untuk memfasilitasi dan meningkatkan intensitas dan kualitas belajar pada diri peserta didik. Pembelajaran harus menghasilkan belajar, tapi tidak semua proses belajar terjadi karena pembelajaran, proses belajar juga bisa terjadi dilingkungan sosial-kultural dalam lingkungan masyarakat 
(Wiranataputra, Udin.S, 2007 :I.18) Pembelajaran menurut Pasal I butir 20 UU No. 20 Tahun 2003 tentang Sisdiknas, yakni "Pembelajaran adalah proses interaksi peserta didik dengan pendidik dan sumber belajar pada suatu lingkungan belajar." Dalam konsep tersebut terkandung 5 konsep, yaitu interaksi, peserta didik, pendidik, sumber belajar dan lingkungan belajar. Pembelajaran dalam konteks formal, adalah Sekolah, pendidikan di sekolah yang terjadi di kelas dan lingkunagn sekolah. Namun sebagian kecil pembelajaran bisa terjadi pada lingkungan masyarakat seperti, ko-kurikuler (kegiatan diluar kelas dalam rangka tugas suatu mata pelajaran), Ekstrakurikuler (kegiatan di luar mata pelajaran, di luar kelas), dan Ekstramural (kegiatan yang dilakukan diluar kurikulum sekolah). Sedangakan pembelajaran dalam kontek nonformal banyak terjadi di lingkunagn masyarakat, termasuk dunia kerja, media massa dan internet.

Pembelajaran merupakan hal yang paling penting dilakukan dalam bentuk kegiataan apapun, salah satunya pada pemahaman tentang ekonomi khususnya dalam Islam, karena saat ini pemahamn tersebut sangat kompleks untuk dipaahami setiap orang dalam menunjang kehidupannya.

Setiap paham ekonomi memiliki karakter tertentu yang dibedakan dengan paham yang lainnya satu paham, termasuk ekonomi, dibangun oleh suatu tujuan, prinsip, nilai, dan paradigma (P3El. 2008. 53). Ekonomi Islam dibangun untuk tujuan suci, dituntun oleh ajaran Islam dan dicapai dengan cara-cara yang dituntun pula oleh ajaran islam oleh kareena it, kesemua hal tersebut saling terkait dan terstrukur secara hierarkis, dalam arti bahwa semangat ekonomi Islam tercermin dari tujuanya, dan ditopang oleh pilarnya. Untuk mencapai falah hanya bisa dicapai dengan pilar ekonomi Islam, yaitu nilai-nilai dasar, dan pilar operasional, yang tercermin dalam prinsip-prinsip ekonomi (Islamic principles). (P3El. 2008. 53).

Menurut hasil penelitian Martin Van Bruinessen terhadap 18 Pesantren di Jawa Timur diungkapkan bahwa pembelajaran fiqih yang dilakukan dari setiap pesantren berbeda walaupun kitab fiqih yang digunakan sama.(Asmawi, 20I2. 45). Di sisi lain, berdasarkan observasi awal penelitian ini terhadap pembelajaran ekonomi Islam pada pondok pesantren di Kalimantan Tengah, pada tiga pondok pesantren di Kalimantan Tengah yaitu pondok pesantren Hidayatul Insan, Darul Ulum, dan Miftahul Jannah ditemukan bahwa pembelajaran fiqih yang dilaksanakan lebih menekankan pada penguasaan materi daripada kemampuan santri dalam mentransformasikan ajaran fiqih ke dalam dinamika kehidupan masyarakat. Padahal keberagamaan umat Islam di Kalimantan Tengah cukup dinamis dengan tumbuh suburnya majelis-majelis ta'lim yang diantaranya memberikan pemahaman ajaran Islam yang inklusif. Karena itu, untuk mengetahui lebih jauh peta keberagamaan umat Islam masa kini, peneliti tertarik untuk melakukan penelitian lebih mendalam dengan mengangkat satu judul penelitian yakni Pembelajaran Ekonomi Islam pada Pondok Pesantren di Kalimantan Tengah.

\section{Rumusan Masalah}


Berdasarkan dari latar belakang dan masalah di atas, maka dapat dirumuskan permasalahan penelitian ini difokuskan pada "Bagaimana pembelajaran ekonomi dalam Islam pada materi Mudharabah di pondok pesantren"

\section{Tujuan Penelitian}

Pada rumusan masalah di atas bahwa secara rinci penelitian ini bertujuan untuk mendeskripsikan pembelajaran ekonomi dalam Islam pada materi Mudharabah di pondok pesantren.

\section{Manfaat Penelitian}

Secara teoretis penelitian ini dapat dijadikan sebagai bahan acuan untuk mengembangkan ilmu pembelajaran ekonomi Islam. selain itu, sebagai bentuk upaya pemahaman terhadap seseorang tentang pembelajaran ekonomi Islam agar generasi mendatang dapat memahaminya. Secara praktis penelitian ini dapat digunakan sebagai bahan acuan bagi pelaku dalam dunia pendidikan. Selain itu, dapat juga sebagai bahan bacaan bagi masyarakat agar tidak hanya tau dalam ekonomi secara umum, tetapi memahami dalam pembelajaran ekonomi secara Islam.

\section{Metode}

\section{Lokasi Penelitian}

lokasi penelitian ini dilakukan pada pondok pesantren.

\section{Pendekatan Penelitian}

Pendekatan yang digunakan dalam penelitian ini adalah pendekatan kualitatif.

\section{Subjek, Objek, dan Informan Penelitian}

I. Subjek
Subjek dalam penelitian ini yaitu ustadz dan ustadzah.

2. Objek

Objek dalam penelitian ini adalah pembelajaran ekonomi dalam Islam pada materi Mudharabah.

\section{Informan}

Informan dalam penelitian ini yaitu pimpinan yayasan, santri.

\section{Teknik Pengumpulan Data}

Untuk mendapatkan data yang diperlukan dalam penelitian, ada beberapa teknik yang digunakan yaitu:

I. Teknik Observasi

Teknik observasi sangat diperlukan dlam setiap jenis penelitian, demikian juga dalam penelitian ini, penulisan menggunakan teknik observasi untuk menggali data dengan cara melakukan pengamatan terhadap subjek dengan segala perilakunya.

Observasi adalah pengamatan dan pencatatan yang sistematis terhadap gejala-gejala yang diteliti.

2. Teknik Wawancara

Merupakan teknik pengumpulan data yang dilakukan dengan cara memberi seperangkat pertanyaan secara lisan kepada responden.

3. Teknik Dokumentasi

Menurut Moleong, dokumentasi adalah setiap bahan tertulis, film dan gambar yang dapat memberikan informasi.

\section{Teknik Pengolahan Data}

Langkah-langkah yang ditempuh dalam pengolahan data adalah sebagai berikut. 
1. Peneliti mencatat, dan menyimak kembali data rekaman dari hasil wanwancara dengan subjek dan informan.

2. Memilah data yang diperoleh dari hasil observasi, wawancara, dan dokumentasi;

3. Peneliti mengidentifikasi data yang terkait dengan pembelajaran ekonomi Islam;

4. Mengklasifikasi data berdasarkan kelompok masalah penelitian;

5. Peneliti menganalisis seluruh data berdasarkan masalah yang diteliti;

6. Mencek keabsahan data, dan

7. Melakukan evaluasi semua masalah yang diperoleh dan menarik simpulan yang tepat.

\section{Teknik Analisis Data}

Data dalam penelitian menggunakan teknik analisis secara kualitatif, yaitu menganalisis "Pembelajaran Ekonomi dalam Islam Pada Materi Syirkah di Pondok Pesantren". Analisis data dalam penelitian kualitatif dilakukan pada saat pengumpulan data berlangsung dan setelah selesai pengumpulan data dalam periode tertentu (Sugiono, 2010:337). Adapun langkahlangkah yang ditempuh dalam analisis data adalah sebagai berikut:

1. Mereduksi Data

Tahap mereduksi data, dilakukan melalui proses penyeleksian, identifikasi dan pengklasifikasian. Penyeleksian dan pengidentifikasian merupakan kegiatan untuk menyeleksi dan mengidentifikasi data-data pada kategori pembelajaran ekonomi dalam Islam. Tahap pengklasifikasian merupakan proses yang dilakukan untuk mengklasifikasikan data, memilih data dan mengelompokkan data. Pada tahap mereduksi data, ada bagian yang dihilangkan, yaitu data tidak relevan dengan tujuan penelitian.

2. Menyajikan Data

Menyajikan data merupakan kegiatan pengelompokkan data melalui tahap reduksi data pada kategori pembelajaran ekonomi dalam Islam pada materi Mudharabah di Pondok Pesantren.

3. Menarik Simpulan

Simpulan ditarik setelah data disusun dan diperiksa kembali. Selanjutnya, didiskusikan dengan teman sejawat. Setelah proses ini dilalui, barulah dapat ditarik simpulan menganai pembelajaran ekonomi dalam Islam pada materi Mudharabah di Pondok Pesantren.

\section{Pembahasan}

\section{A. Pembelajaran Ekonomi Syariah Dengan Materi Murabahah}

Permendiknas RI No. 52 Tahun 2008 sebagaimana dikemukakan Akhmad Sudrajat (2009) tentang Standar Proses disebutkan bahwa tujuan pembelajaran memberikan petunjuk untuk memilih isi mata pelajaran, menata urutan topik-topik, mengalokasikan waktu, petunjuk dalam memilih alat-alat bantu pengajaran dan prosedur pengajaran, serta menyediakan ukuran (standar) untuk mengukur prestasi belajar siswa. Pembelajaran merupakan kegiatan yang dilakukan oleh guru secara terprogram dalam disain instruksional yang 
menciptakan proses interaksi antara sesama peserta didik, guru dengan peserta didik dan dengan sumber belajar. Pembelajaran bertujuan untuk menciptakan perubahan secara terusmenerus dalam perilaku dan pemikiran siswa pada suatu lingkungan belajar.

Pada materi ini pembahasan kedua melanjutkan setelah teori jual beli yang berada di semester genap kelas $X$ dan bagian terpenting juga yang harus diberikan, karena sangat pentingnya materi ini guru yang mengajar yaitu bapak aspirinor guru mata pelajaran Fiqh di Madrasah Aliyah Hidayatul Insan Fii Ta'limiddin Palangka Raya, menjelaskan secara detail bagaimana proses pembelajaran yang dilakukan pada materi Khiyar. Dalam silabus pada materi ini menjelaskan beberapa sub tema yaitu menjelaskan dan mempraktikkan tentang murabahah dengan benar.

I. Seperti apa persiapan yang dilakukan seorang pendidik sebelum melaksanakan pembelajaran pada materi Murabahah?

Pada persiapan kali ini tidak jauh berbeda dengan materi awal yaitu sesuai dengan tuntutan pada silabus yang mengharuskan siswanya lebih aktif maka diperlukan beberapa plan dalam menentukan beberapa hal penunjang proses pembelajaran, salah satunya perangkat pembelajaran yang berupa rpp sesuai dengan peraturan pemerintahnya dengan apa yang ada dipanduan silabus serta petunjuk yang ada dibukunya untuk mengambil materi yang akan diajarkan. Dan kemudiaan perangkat lainnya dipersiapkan seadanya seperti video-video untuk menunjang proses pembelajaran yang berbentuk Islami sifatnya syar'i karena posisinya pada Madrasah Aliyah dalam pondok pesantren. Video yang diberikan dalam proses pembelajaran ini berupa transaksi animasi dengan durasi 10-15 menit dan didapatkan melalui mahasiswa yang sedang praktik mengajar saat itu untuk membuatnya. Persiapan yang lainnya juga dibutuhkan beberapa barang untuk didemonstrasikan saat pembelajaran dalam kelas.

2. Seperti apa pelaksanaan yang dilakukan seorang pendidik sebelummelaksanakan pembelajaran pada materi Murabahah?

Pada proses ini diwali dengan kegiatan pendahuluan yaitu memberikan stimulus terlebih dahulu kepada peserta didik untuk proaktif dalam pembelajaran yang nantinya akan dilaksanakan serta menampilkan beberapa permasalahan dalam kehiduan yang terkait pada materi pembelajaran. Kemudian dilanjutkan dengan kegiatan inti diawali dengan mengamati seperti meminta peserta didik untuk membaca buku referensi tentang murabahah dan juga diberikan kesempatan untuk mengamati beberapa permasalan apa yang terjadi terkait dengan materi yang dibahas serta mengamati slide yang ditampilkan. Selanjutnya dilakukan proses menanya degan 
proses peserta didik untuk menjawab pre test yang diberikan berupa pertanyaan, kemudian memberikan kesempatan peserta didik untuk mengajukan pertanyaan terkait hasil pengamatan yang dilakukan sebelumnya tentang syirkah serta menampung pertanyaan dari mereka dan memberi kesempatan kepada tiap peserta didik atau menunjuk secara acak menjawab pertanyaan dari temannya. Setelah dilakukan pengamatan dan menanya dilanjutkan dengan mengeksplorasi beberapa hasil yang dilakukan sebelumnya seperti mencari jawaban pada pertanyaan pre test dengan membaca beberapa referensi yang terdapat dibuku ajar atau refferensi buku lainnya, kemudian pada kegiatan ini mengumpulkan informasi dari Tanya jawab yang dilakukan dan melengkapinya dengan membaca buku ajar dn buku referensi lainnya terkait materi murabahah serta dilakukan diskusi terhadp permasalahan yang didapatkan. Selanjutnya mengasosiasikan dengan menyusun dan menyimpulkan hasil laporan yang telah didiskusikan oleh peserta didik. Pada kegiatan inti diakhiri dengan mengkomunikasikan mengajak peserta didik membuat laporan hasil diskusi yang sudah dilakukan dengan cara mempresetasikan didepan kelas dan diberikan tanggapan dari kelompok lainnya dan diakhiri penegasan terhadap hasil pembelajaran yang dilakukan oleh guru.

Pada

pelaksanan pembelajaran ini dilakukan sesuai dengan program pemerintah yang mengharuskan untuk melaksanakan sebuah pembelajaran dengan pendekatan saintifik yang termuat dalam kurikulum 20I3, kurikulum ini hasil dari pengembangan dan evaluasi dari kurikulum sebelumnya yaitu kurikulum tingkat satuan pendidikan (KTSP), yang mengarahkan kepada siswa yang lebih berperan dalam proses pembelajaran tersebut. Madrasah Aliyah Hidayatul Insan baru memulai program kurikulum ini dalam I tahun belakang yaitu dari tahun 2018. Guru di madrasah aliyah berusaha semaksimal mungkin untuk melaksanakan sesuai dengan kurikulum yang di inginkan yaitu dengan pendekatan saintifik, Mengamati dengan metode mengamati mengutamakan kebermaknaan proses pembelajaran. Keunggulan metode mengamati adalah peserta didik senang dan tertantang dan mudah pelaksanaannya. Menanya menurut Kemendikbud mempunyai fungsi sebagai berikut: a) Membangkitkan rasa ingin tahu, minat, dan perhatian peserta didik. b) Mendorong dan menginspirasi peserta didik untuk aktif belajar, serta mengembangkan pertanyaan dari dan untuk dirinya sendiri. c) Mendiagnosis kesulitan belajar 


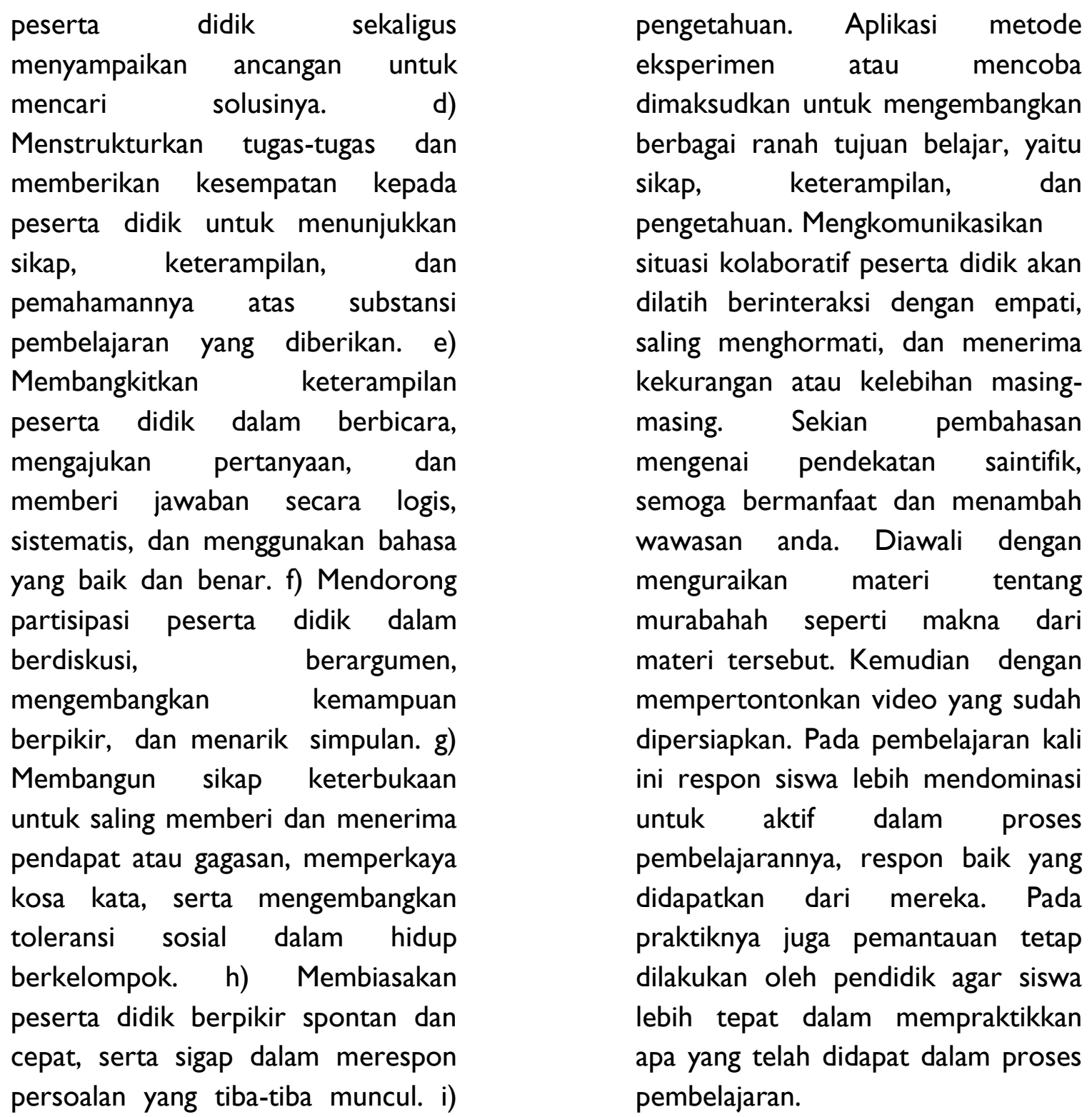

Melatih kesantunan dalam berbicara dan membangkitkan kemampuan berempati satu sama lain. Mengumpulkan data/ Mengekplorasi Mengumpulkan data artinya siswa diajak untuk mengumpulkan pengetahuan sebanyak dari berbagai sumber pengetahuan. Menalar Penalaran adalah proses berfikir yang logis dan sistematis atas fakta empiris yang dapat diobservasi untuk memperoleh simpulan berupa
3. Seperti apa evaluasi yang dilakukan seorang pendidik sebelum melaksanakan pembelajaran pada materi Murabahah?

Pada tahap ini seperti biasa guru bersama peserta didik baik secara individual maupun kelompok mengevaluasi seluruh rangkaian aktivitas pembelajaran dan hasil-hasil yang diperoleh selanjutnya secara melakukan refleksi untuk 
bersama dengan harapan mendapatkan umpan balik terhadap proses dan hasil pembelajaran, kemudian pada proses ini diberikan motivasi dan tugas harian untuk dikerjakan. Pada implementasinya ternyata evaluasi dapat berbeda satu sama lain, hal ini tergantung dari maksud dan tujuan dari evaluasi tersebut dilaksanakan. Seperti evaluasi program pembelajaran tidak akan sama dengan evaluasi kinerja pegawai. Evaluasi program pembelajaran dilakukan dengan ditujuan untuk melihat sejauh mana hasil belajar telah tercapai dengan optimal sesuai dengan target dan tujuan pembelajaran itu sediri. Sedangkan evaluasi kinerja pegawai dilakukan dengan tujuan untuk melihat kualitas, loyalitas, atau motivasi kerja pegawai, sehingga akan menentukan hasil produksi. Dengan adanya perbedaan tersebut lahirlah beberapa model evaluasi yang dapat menjadi pertimbangan evaluator dalam melakukan evaluasi.

Pada prinsipnya saat ini evaluasi dilakukan lebih fokus pada setiap akhir pembelajaran baik itu berupa test ataupun non test. Setiap setelah bab materi selesai selalu dilakukan penilaian untuk mengukur sejauh mana siswa memahami tentang materi yang diajarkan dengan tertulis, tetapi juga terkadang sebelum tertulis dilakukan diskusi Tanya jawab (pertanyaan lemparan) kepada beberapa siswa yang berani untuk menjawabnya. Dan juga pda kurikulum ini penilaian di tuntut untuk dilakukan beberapa aspek pada kognitif, afektif, dan psikomotornya yang harus tertera dalam penilaian setiap peserta didik. terkadang diberikan perintah untuk mengerjakan ulangan harian denngan jujur dan tertib di kelas.

\section{Daftar Pustaka}

Asmawi, Studi Hukum Islam: Dari TekstualisRasionalis Sampai Rekonsiliatif (Yogyakarta: Teras. 2012

Pusat Pengkajian dan Pengembangan Ekonomi Islam (P3El), Ekonomi Islam. Jakarta: PT Raja Grafindo Persada, 2012

Al Arif, M. Nur Rianto dan Euis Amalia, Teori Mikroekonomi: Suatu Perbandingan Ekonomi Islam dan Ekonomi Konvensional, Jakarta: Kencana, 2010

M. A Mannan, Ekonomi Islam: Teori dan Praktek, Jakarta: PT. Intermasa, 1992

Ahmad Muhammad Al-assal dan Fathi Ahmad Abdul Karim, Sistem Ekonomi Islam, Prinsip-Prinsip Dan Tujuan-Tujuannya, Surabaya: PT Bina Ilmu, 1980

Rahman, Afzalur, Doktrin ekonomi Islam Jilid I, Yogyakarta: Dana Bhakti Wakaf, 1995

Sudarsono, M.B, Hendri, Pengantar Ekonomi Mikro Islam, Yogyakarta, Ekonosia, 2002 Zainuddin Ali, Hukum Ekonomi Syariah, Jakarta: Sinar Grafika Offset, 2008 